\title{
Practical Guidance in Perioperative Management of Immunosuppressive Therapy for Rheumatology Patients Undergoing Elective Surgery
}

\author{
Michelle Boyce and Anne Massicotte
}

\section{INTRODUCTION}

Curgical site infections are an important cause of prolonged hospitalization, with an associated mortality rate of $3 \% .^{1}$ The incidence of a surgical site infection after surgery is $2 \%$ to $5 \%$, and among surgical patients, such infections are the most common type of health care-associated infection. ${ }^{2}$ Patients who are receiving immunosuppressive therapy may be at increased risk of a postsurgical infection and delayed wound healing. ${ }^{3}$ In addition, multiple other contributing factors may increase the risk of infection after surgery, including (but not limited to) prolonged surgery (> $2 \mathrm{~h}$ ), advanced age, obesity, smoking, cancer, other immunocompromising conditions, diabetes, and abdominal surgery. ${ }^{4}$ The risk of infection depends on whether the surgery is performed in a clean, sterile environment and considered low risk (e.g., cataract surgery, arthroscopy), or the surgery is performed in a contaminated, dirty environment and considered high risk (e.g., abdominal or gastrointestinal surgery)., ${ }^{3,5}$ Furthermore, the type of surgical wound may be classified as clean, cleancontaminated, contaminated, and dirty/infected, as defined by the US Centers for Disease Control and Prevention, ${ }^{1}$ with each classification associated with a different degree of risk for a surgical site infection. ${ }^{4}$ At the same time, the severity of the patient's underlying disease is an important factor to consider when determining perioperative drug management. ${ }^{6}$ For example, if the disease is severe, holding immunosuppressants may result in a negative outcome, such as a disease flare or relapse, whereas a patient with mild disease may tolerate temporary discontinuation of therapy. Hence, a risk-benefit assessment for each patient is warranted. ${ }^{6,7}$

This article aims to provide guidance to clinical practitioners for the perioperative management of rheumatology patients who are receiving immunosuppressive therapy and for whom elective surgery is planned. This guidance is a collection of recommendations from national rheumatology associations and other groups of rheumatology specialists. For the purpose of this review, immunosuppressive therapy includes common traditional diseasemodifying antirheumatic drugs, as well as biologic agents used for rheumatoid diseases.

\section{METHODS}

A formal literature search in Ovid MEDLINE and PubMed was conducted to gather relevant articles. The search terms, either as MESH words or keywords, were disease modifying antirheumatic drug*, DMARD*, immunosuppressive agents, biologic*, monoclonal antibodies, tumor necrosis factor-alpha, rheumatic diseases, practice guideline*, recommendation*, consensus, surgical procedures, surgery, and operative (peri, pre, intra, post). Searches were limited to guidelines and review articles addressing the perioperative use of immunosuppressants. A general Google search was also performed to capture other possibly relevant material that would not have been formally indexed. After removal of duplicates, irrelevant articles (i.e., those that did not substantially address our topic), and articles written in languages other than French or English, 4 national guidelines and 4 review articles remained as the best available evidence. Most of the data that we reviewed focused on patients with rheumatic diseases, and we therefore limited this guidance document to this patient population.

\section{RESULTS}

The literature search revealed a lack of prospective studies establishing the optimal withhold and restart times for immuno- 
suppressants during the perioperative period. As such, the recommendations and reviews retrieved through the literature search focused on guiding principles (e.g., type of surgery, drug half-life, and drug dosing interval).

Table 1 summarizes management recommendations for rheumatology patients during the perioperative period of elective surgeries for common immunosuppressants marketed in Canada. ${ }^{3,5-14}$ Canadian recommendations have been prioritized as much as possible (in Table 1, see the recommendations originating from reference 3). The information in this table applies only to rheumatology patients and does not cover other populations, such as transplant patients, who may be at risk of organ rejection if immunosuppressive therapy is stopped temporarily.

The table separates "all surgeries" from "total hip and total knee arthroplasty" for the following 2 reasons: first, the references cited in these 2 categories adopted a very different approach for the perioperative management of immunosuppressants, and second, the US recommendations are specific to patients undergoing elective total hip or total knee arthroplasty. The table also provides, in many cases, 2 different options for "all surgeries" (i.e., not limited to a specific type of surgery), reflecting the lack of consensus on the perioperative management of immunosuppressants.

When determining the period for which a drug should be held before surgery, the elimination half-life $\left(t_{1 / 2}\right)$ of each immunosuppressant and its metabolites is a useful tool..$^{3,5,14}$ Most of the guidelines recommend holding a drug for 2 to 3 half-lives if the surgery carries a low risk of infection, and for 5 half-lives if the surgery carries a high risk of infection. ${ }^{3,5}$ In Table 1, the minimum of 2 (or in some cases 3) half-lives and maximum of 5 half-lives are stated with the actual calculated time in parentheses for each drug; if there is a range of half-lives, the range of time to hold the drug is stated. The reported half-life of a particular drug may differ among sources in the literature, and therefore the time to hold the drug, as stated in Table 1, may differ slightly from the quoted references. Clinical judgment will be of primary importance when applying these recommendations to special populations such as elderly patients and those with renal or hepatic impairment, given likely differences in pharmacokinetic parameters.

In the context of total hip and total knee arthroplasty, the recommendations in the US guidelines are based on the drug dosing interval rather than drug half-life, because the half-life does not always correlate with each drug's duration of action. ${ }^{9}$ The US recommendation is to schedule the surgery at the end the drug dosing interval, when it would normally be the time to proceed with the next dose. ${ }^{9}$

In addition to the type of surgery, drug half-life, and drug dosing interval, addressed in Table 1, the final decision about the exact duration of drug-holding should still be individualized according to patient-specific risk factors and comorbidities.
Before restarting an immunosuppressant postoperatively, evaluation of the wound is important to ensure adequate healing, because re-initiation of immunosuppressive therapy too early can put the patient at increased risk of postoperative infection. Most of the available guidelines recommend resuming the immunosuppressive therapy when there are no signs of infection and there is evidence of satisfactory wound healing. ${ }^{3,5,14}$

\section{HYPOTHETICAL CASE STUDIES: APPLICATION OF PRACTICAL GUIDANCE}

\section{Case 1}

A 34-year-old woman with breast cancer is scheduled to undergo an elective mastectomy. She has rheumatoid arthritis that has been well controlled over the past 2 years with adalimumab $40 \mathrm{mg} \mathrm{SC}$ every 2 weeks and methotrexate $7.5 \mathrm{mg}$ orally once weekly. She has no renal or hepatic impairment. Using Table 1 as a guide, we could recommend holding the adalimumab for 28 days before surgery (given that a mastectomy is generally classified as a clean surgical procedure) and continuing the methotrexate throughout the perioperative period. The patient could resume adalimumab therapy when there is no evidence of infection and wound healing is satisfactory.

\section{Case 2}

A 60-year-old man with psoriatic arthritis receives infliximab by infusion every 4 weeks, with his most recent infusion administered on March 2. The patient has responded well to infliximab and has not experienced any flares of his disease in the past year. He is scheduled to undergo an elective total hip arthroplasty. The orthopedic surgeon is wondering for how long the infliximab should be held before the surgery. According to Table 1, it would be best to schedule the surgery during the week of March 30 (at the end of the infliximab dosing interval, i.e., during week 5) and to hold the dose scheduled for March 30. The patient could resume his infliximab infusions at least 14 days after surgery, when there is no evidence of infection and wound healing is satisfactory.

\section{CONCLUSION}

Patients who are receiving immunosuppressive therapy may be at increased risk of infection after surgery; therefore, holding immunosuppressants may be warranted in the perioperative period. However, holding immunosuppressants may result in a flare of the underlying disease. This review has summarized practical guidance addressing this issue for rheumatology patients. Table 1 is provided as a guide in the decision-making process, but final decisions should be tailored to each patient, balancing the risks and benefits of holding or continuing therapy. Factors to consider when deciding to continue or hold an immunosuppressant drug include the type of surgery, comorbidities, severity of the disease, and any other factor that could contribute to the 
Table 1 (part 1 of 4). Perioperative Management of Immunosuppressive Therapy for Adult Rheumatology Patients*

\begin{tabular}{|c|c|c|c|c|}
\hline \multirow{2}{*}{$\begin{array}{l}\text { Generic Name and } \\
\text { Approved Indicationst }\end{array}$} & \multirow{2}{*}{ Approved Dosaget ${ }^{8}$} & \multirow{2}{*}{$\begin{array}{l}\text { Half-life } \\
\left(t_{1 / 2}\right)^{8,12,13}\end{array}$} & \multicolumn{2}{|c|}{ Perioperative Recommendations } \\
\hline & & & Preoperative & \multirow{2}{*}{\begin{tabular}{l}
\multicolumn{1}{c}{ Postoperative } \\
All surgeries $3,5,14$ \\
Restart when there is no evidence \\
of infection, and wound healing is \\
satisfactory
\end{tabular}} \\
\hline \multirow{7}{*}{$\begin{array}{l}\text { Abatacept } \\
\text { Psoriatic arthritis, } \\
\text { rheumatoid arthritis }\end{array}$} & \multirow{7}{*}{$\begin{array}{l}\text { 500-1000 mg } \\
\text { IV q4weeks } \\
125 \text { mg SC once weekly }\end{array}$} & \multirow{7}{*}{ 13-14 days } & \multirow{4}{*}{$\begin{array}{l}\text { All surgeries, option } 1 \\
\text { Clean surgery } \ddagger^{3} \text { : } \\
\text { Hold for } 2 \times t_{1 / 2}(26-28 \text { days }) \\
\text { Contaminated/dirty surgery }{ }^{3,5} \text { : } \\
\text { Hold for } 5 \times t_{1 / 2}(65-70 \text { days })\end{array}$} & \multirow{5}{*}{$\begin{array}{l}\text { All surgeries } 3,5,14 \\
\text { Restart when there is no evidence } \\
\text { of infection, and wound healing is } \\
\text { satisfactory }\end{array}$} \\
\hline & & & & \\
\hline & & & & \\
\hline & & & & \\
\hline & & & $\begin{array}{l}\text { All surgeries, option } 2^{10} \\
\text { Hold for } 25 \text { days }\end{array}$ & \\
\hline & & & Total hip and total knee arthroplasty ${ }^{-}$ & \\
\hline & & & $\begin{array}{l}\text { Schedule surgery at the end of the } \\
\text { dosing interval (during week } 2 \text { or } 5 \text { ) }\end{array}$ & $\begin{array}{l}\text { Restart at least } 14 \text { days after surgery, } \\
\text { when there is no evidence of infection, } \\
\text { and wound healing is satisfactory }\end{array}$ \\
\hline \multirow{5}{*}{$\begin{array}{l}\text { Adalimumab } \\
\text { Ankylosing spondylitis, } \\
\text { psoriatic arthritis, } \\
\text { rheumatoid arthritis }\end{array}$} & \multirow[t]{5}{*}{40 mg SC q2weeks } & \multirow[t]{5}{*}{14 days } & All surgeries, option 1 & \multirow{4}{*}{$\begin{array}{l}\text { All surgeries }{ }^{3,5} \\
\text { Restart when there is no evidence of } \\
\text { infection, and wound healing is } \\
\text { satisfactory }\end{array}$} \\
\hline & & & & \\
\hline & & & $\begin{array}{l}\text { Contaminated/dirty surgery }{ }^{3,5} \text { : } \\
\text { Hold for } 5 \times t_{1 / 2}(70 \text { days })\end{array}$ & \\
\hline & & & $\begin{array}{l}\text { All surgeries, option } 2^{10} \\
\text { Hold for } 30 \text { days }\end{array}$ & \\
\hline & & & $\begin{array}{l}\text { Total hip and total knee arthroplasty } \\
\text { Schedule surgery at the end of the } \\
\text { dosing interval (during week } 2 \text { or } 3 \text { ) }\end{array}$ & $\begin{array}{l}\text { Restart at least } 14 \text { days after surgery, } \\
\text { when there is no evidence of infection, } \\
\text { and wound healing is satisfactory }\end{array}$ \\
\hline Anakinra & 100 mg SC daily & $4-6 h$ & $\begin{array}{l}\text { All surgeries, option } 110 \\
\text { Hold for } 1-2 \text { days before surgery }\end{array}$ & $\begin{array}{l}\text { All surgeries }{ }^{11} \\
\text { Restart } 1-2 \text { weeks after the procedure }\end{array}$ \\
\hline
\end{tabular}

Rheumatoid arthritis

All surgeries, option $2^{11}$

Hold for the week of surgery

Total hip and total knee arthroplasty ${ }^{-1}$ Total hip and total knee arthroplasty ${ }^{-1}$

Schedule surgery at the end of the Restart at least 14 days after surgery, dosing interval (during day 2) when there is no evidence of infection, and wound healing is satisfactory

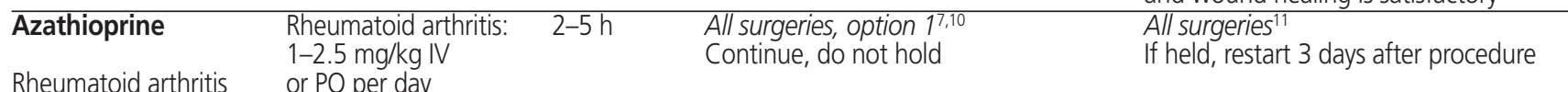

May be used clinically or PO per day

for SLE (not approved

SLE: Not applicable

All surgeries, option $2^{11}$

Hold for 1 day before surgery

Total hip and total knee arthroplasty ${ }^{9}$ Total hip and total knee arthroplasty ${ }^{9}$

by Health Canada)

Severe SLE: Continue, do not hold Severe SLE: Not applicable

Not-severe SLE: Hold for 1 week before surgery

Not-severe SLE: Restart 3-5 days after surgery, when there is no evidence of infection, and wound healing is satisfactory

\begin{tabular}{lll}
\hline Belimumab & $10 \mathrm{mg} / \mathrm{kg}$ IV q4weeks & $18-19$ days \\
SLE & $200 \mathrm{mg}$ SC weekly & S
\end{tabular}

All surgeries All surgeries

No recommendation stated No recommendation stated

Total hip and total knee arthroplasty ${ }^{9}$ Total hip and total knee arthroplasty ${ }^{9}$ Schedule surgery at the end of the Restart at least 14 days after surgery, dosing interval (during week 5) when there is no evidence of infection,

NoтE: The guideline does not address and wound healing is satisfactory patients on an SC weekly regimen; in this case, scheduling the surgery at the end of the dosing interval, i.e., during week 2 , is a reasonable option. 
This single copy is for your personal, non-commercial use only.

For permission to reprint multiple copies or to order presentation-ready copies for distribution, contact CHP at publications@cshp.ca

Table 1 (part 2 of 4). Perioperative Management of Immunosuppressive Therapy for Adult Rheumatology Patients*

\begin{tabular}{|c|c|c|c|c|}
\hline \multirow{2}{*}{$\begin{array}{l}\text { Generic Name and } \\
\text { Approved Indicationst }\end{array}$} & \multirow{2}{*}{ Approved Dosaget ${ }^{8}$} & \multirow{2}{*}{$\begin{array}{l}\text { Half-life } \\
\left(t_{1 / 2}\right)^{8,12,13}\end{array}$} & \multicolumn{2}{|c|}{ Perioperative Recommendations } \\
\hline & & & Preoperative & Postoperative \\
\hline \multirow{3}{*}{$\begin{array}{l}\text { Certolizumab pegol } \\
\text { Ankylosing spondylitis, } \\
\text { nr-Ax SpA, psoriatic } \\
\text { arthritis, rheumatoid }\end{array}$} & 200 mg SC q2weeks & \multirow[t]{3}{*}{14 days } & All surgeries, option 1 & \multirow{3}{*}{$\begin{array}{l}\text { All surgeries } 3,5 \\
\text { Restart when there is no evidence of } \\
\text { infection, and wound healing is } \\
\text { satisfactory }\end{array}$} \\
\hline & 400 mg SC q4weeks & & Hold for $2 \times t_{1 / 2}(28$ days $)$ & \\
\hline & & & Contaminated/dirty surgery3,5: & \\
\hline
\end{tabular}
然 Hold for $5 \times t_{1 / 2}$ (70 days)

All surgeries, option $2^{10}$

Hold for 28 days

Total hip and total knee arthroplasty ${ }^{-}$Total hip and total knee arthroplasty ${ }^{9}$ Schedule surgery at the end of the Restart at least 14 days after surgery, dosing interval (during week 3 or 5) when there is no evidence of infection, and wound healing is satisfactory

\begin{tabular}{|c|c|c|}
\hline $\begin{array}{l}\text { Cyclosporine } \\
\text { Rheumatoid arthritis }\end{array}$ & $\begin{array}{l}\text { Rheumatoid arthritis: } 8-19 \mathrm{~h} \\
1.25-2.5 \mathrm{mg} / \mathrm{kg} \\
\text { PO q12h }\end{array}$ & $\begin{array}{l}\text { All surgeries } \\
\text { Hold for } 1 \text { week before surgery } \\
\text { Total'hip and total knee arthropla. } \\
\text { Severe SLE: Continue, do not holo }\end{array}$ \\
\hline $\begin{array}{l}\text { May be used clinically } \\
\text { for SLE (not approved } \\
\text { by Health Canada) }\end{array}$ & SLE: Not applicable & $\begin{array}{l}\text { Not-severe SLE: Hold for } 1 \text { week } \\
\text { before surgery }\end{array}$ \\
\hline
\end{tabular}
All surgeries ${ }^{10}$
Restart 1 week after surgery Total hip and total knee arthroplasty
Severe SLE: Not applicable

$\begin{array}{lll}50 \mathrm{mg} \text { SC weekly } & 102 \mathrm{~h} & \text { All surgeries, option } 1 \\ 25 \mathrm{mg} \mathrm{SC} \text { twice weekly } & \text { Clean surgery } \neq^{3}: \\ & \text { Hold for } 2 \times t_{1 / 2}(9 \text { days }) \\ & \text { Contaminated/dirty surgery } 3,5: \\ & \text { Hold for } 5 \times t_{1 / 2}(21 \text { days })\end{array}$

Not-severe SLE: Restart 3-5 days after surgery, when there is no evidence of infection, and wound healing is satisfactory

Etanercept
Active arthritis,
ankylosing spondylitis,
psoriatic arthritis,
All surgeries, option $2^{10}$
Hold for 10 days

Total hip and total knee arthroplasty ${ }^{-\cdots}$ Total hip and total knee arthroplasty ${ }^{9}$

Schedule surgery at the end of the Restart at least 14 days after surgery, dosing interval (during week 2) when there is no evidence of infection,

All surgeries $3,5,14$

Restart when there is no evidence of infection, and wound healing is
satisfactory rheumatoid arthritis
All surgeries, option 1
Clean surgery $\ddagger^{3}$ :
Hold for $2 \times t_{1 / 2}$ (28 days)
Contaminated/dirty surgery3,5:
Hold for $5 \times t_{1 / 2}(70$ days $)$

Ankylosing spondylitis $2 \mathrm{mg} / \mathrm{kg}$ IV q8weeks

$\begin{array}{ll}14 \text { days } & \text { All surgeries, option } 1 \\ & \text { Clean surgery } \neq^{3} \text { : } \\ & \text { Hold for } 2 \times t_{1 / 2} \text { (28 days) }\end{array}$
and wound healing is satisfactory

Golimumab
Ankylosing spondylitis
(SC/NV),
$\mathrm{Nr}-\mathrm{Ax} \mathrm{SpA}(\mathrm{SC})$,
psoriatic arthritis (SC/IV),
rheumatoid arthritis (SC/M)

All surgeries $3,5,14$

Restart when there is no evidence of infection, and wound healing is satisfactory

All surgeries, option $2^{10}$

Hold for 28 days

Total hip and total knee arthroplasty ${ }^{9}$

Schedule surgery at the end of the dosing interval (during week 5 or 9 )

Total hip and total knee arthroplasty ${ }^{9}$ Restart at least 14 days after surgery, when there is no evidence of infection, and wound healing is satisfactory

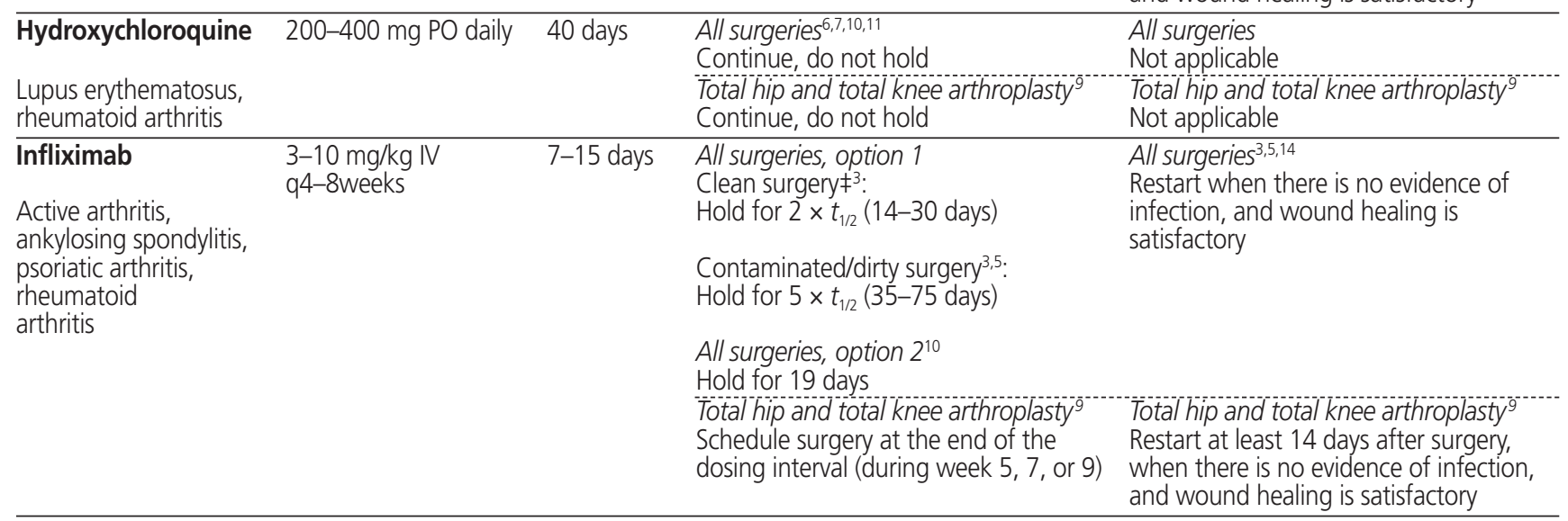


Table 1 (part 3 of 4). Perioperative Management of Immunosuppressive Therapy for Adult Rheumatology Patients*

\begin{tabular}{l}
$\begin{array}{l}\text { Generic Name and } \\
\text { Approved Indications } t^{8}\end{array}$ \\
\hline Leflunomide \\
Lpproved Dosage ${ }^{8}$
\end{tabular}

Rheumatoid arthritis

\section{Half-life}

$\left(t_{1 / 2}\right)^{8,12,13}$

14-19 days; may be prolonged because of enterohepatic All surgeries, option $2^{10,11}$ recycling

cholestyramine washout§

All surgeries, option
Hold for 2 weeks

Preoperative

All surgeries, option $1^{7}$

Hold for 1 week before, and do a

Total hip and total knee arthroplasty Continue, do not hold

\begin{tabular}{ll}
\hline Methotrexate & Psoriatic arthritis: \\
& SC/M/M $/ 1$ \\
Psoriatic arthritis, & $10-25 \mathrm{mg}$ per week \\
rheumatoid arthritis & PO, 7.5-25 mg per week
\end{tabular}

Rheumatoid arthritis: SC/IM/IV/PO,

7.5-20 mg per week

All surgeries, option 13,5,7,10

Continue, do not hold

All surgeries, option $2^{6,10,11}$

Hold for 1 week before only in

surgery; significant kidney, liver, or

lung disease; high-dose steroids; exceptional situations (e.g., complex uncontrolled diabetes mellitus)

Total hip and total knee arthroplasty ${ }^{9}$ Total hip and total knee arthroplasty ${ }^{9}$ Continue, do not hold

Mycophenolate
mofetil and
sodium/acid
No rheumatology
indications approved
by Health Canada;
may be used clinically
for SLE

Rituximab

Rheumatoid arthritis
Not applicable

8-18h

All surgeries ${ }^{10}$

Hold for 1 week before surgery

Total"hip and total knee arthroplasty

Severe SLE: Continue, do not hold

Not-severe SLE: Hold for 1 week before surgery Not applicable

All surgeries ${ }^{10}$
Restart $1-2$ weeks after surgery
Total hip and total' knee arthroplast

Total hip and total knee arthroplasty ${ }$ -

Severe SLE: Not applicable

Not-severe SLE: Restart 3-5 days after surgery when there is no evidence of infection, and wound healing is satisfactory

$\begin{array}{lll}1000 \mathrm{mg} \mathrm{IV} & 18 \text { days } & \begin{array}{l}\text { All surgeries, option } 1 \\ \text { Clean surgery } \ddagger^{3}:\end{array} \\ \text { q2weeks } \times 2 \text { doses } & & \text { Hold for } 2 \times t_{12}(36 \text { days) }\end{array}$

Hold for $2 \times t_{1 / 2}$ (36 days)

All surgeries $3,5,14$

Restart when there is no evidence of infection, and wound healing is
Total hip and total knee arthroplasty ${ }^{9}$ Not applicable

All surgeries ${ }^{6}$

If stopped before procedure, restart the week after surgery if there is no clinical infection, and wound healing is satisfactory
All surgeries ${ }^{10,11}$

Restart 3 days after procedure

Note: Course to be repeated q16-24weeks as needed

Contaminated/dirty surgery 3,5 : Hold for $5 \times t_{1 / 2}$ (90 days) satisfactory

All surgeries, option $2^{10}$

Hold for 100 days

Total hip and total knee arthroplasty ${ }$

Schedule surgery at the end of the dosing cycle (during month 7)

Total hip and tótal knee arthroplasty ${ }^{9}$ Restart at least 14 days after surgery, when there is no evidence of infection, and wound healing is satisfactory

\begin{tabular}{ll}
\hline Secukinumab & $150-300 \mathrm{mg}$ \\
& SC monthly
\end{tabular}

Ankylosing spondylitis, SC monthly

22-31 days

All surgeries

Clean surgery $\ddagger^{5}$ :

Hold for $3 \times t_{1 / 2}(66-93$ days $)$

psoriatic arthritis

Contaminated/dirty surgery ${ }^{5}$.

Hold for $5 \times t_{1 / 2}$ (110-155 days)

Total hip and total knee arthroplasty ${ }^{9}$

Schedule surgery at the end of the dosing interval (during week 5)

All surgeries ${ }^{5}$

Restart when there is no evidence of infection, and wound healing is satisfactory

All surgeries, option $1^{11}$ Hold for 1 day before surgery

All surgeries, option $2^{6}$

Continue, do not hold, unless potential

drug interaction or concern of hepatotoxicity, in which case a hold

for 2 days is recommended

Total hip and total knee arthroplasty ${ }^{9}$ Continue, do not hold

Total hip and total knee arthroplasty ${ }^{9}$ Not applicable 
This single copy is for your personal, non-commercial use only.

For permission to reprint multiple copies or to order presentation-ready copies for distribution, contact CJHP at publications@cshp.ca

Table 1 (part 4 of 4). Perioperative Management of Immunosuppressive Therapy for Adult Rheumatology Patients*

\begin{tabular}{|c|c|c|c|c|}
\hline \multirow{2}{*}{$\begin{array}{l}\text { Generic Name and } \\
{\text { Approved Indications }{ }^{8}}^{8}\end{array}$} & \multirow{2}{*}{ Approved Dosaget $^{8}$} & \multirow{2}{*}{$\begin{array}{l}\text { Half-life } \\
\left(t_{1 / 2}\right)^{8,12,13}\end{array}$} & \multicolumn{2}{|c|}{ Perioperative Recommendations } \\
\hline & & & Preoperative & Postoperative \\
\hline \multirow{2}{*}{$\begin{array}{l}\text { Tacrolimus } \\
\text { Rheumatoid arthritis } \\
\text { (PO only) }\end{array}$} & $\begin{array}{l}\text { Rheumatoid arthritis: } \\
\text { IR, } 3 \text { mg PO once daily }\end{array}$ & $\begin{array}{l}\text { PO, IR: } \\
9-36 \mathrm{~h}\end{array}$ & $\begin{array}{l}\text { All surgeries } \\
\text { No recommendation stated }\end{array}$ & $\begin{array}{l}\text { All surgeries } \\
\text { No recommendation stated }\end{array}$ \\
\hline & SLE: Not applicable & & $\begin{array}{l}\text { Total hip and total knee arthroplasty } \\
\text { Severe SLE: Continue, do not hold }\end{array}$ & $\begin{array}{l}\text { Total hip and total knee arthroplasty }{ }^{9} \\
\text { Severe SLE: Not applicable }\end{array}$ \\
\hline \multicolumn{2}{|l|}{$\begin{array}{l}\text { May be used clinically } \\
\text { for SLE (not approved } \\
\text { by Health Canada) }\end{array}$} & & $\begin{array}{l}\text { Not-severe SLE: Hold for } 1 \text { week } \\
\text { before surgery }\end{array}$ & $\begin{array}{l}\text { Not-severe SLE: Restart 3-5 days after } \\
\text { surgery, when there is no evidence } \\
\text { of infection, and wound healing is } \\
\text { satisfactory }\end{array}$ \\
\hline \multirow{4}{*}{$\begin{array}{l}\text { Tocilizumab } \\
\text { Rheumatoid arthritis } \\
\text { (IV/SC) }\end{array}$} & $\begin{array}{l}4-8 \mathrm{mg} / \mathrm{kg} \\
\text { IV q4weeks }\end{array}$ & $\begin{array}{l}\text { IV: } \\
11-13 \text { days }\end{array}$ & \multirow{2}{*}{$\begin{array}{l}\text { All surgeries, option } 1 \\
\text { Clean surgery } \ddagger^{3} \text { : } \\
\text { Hold for } 2 \times t_{1 / 2} \text { (IV: } 22-26 \text { days; } \\
\text { SC: } 10-26 \text { days) } \\
\text { Contaminated/dirty surgery3,5: } \\
\text { Hold for } 5 \times t_{1 / 2} \text { (IV: } 55-65 \text { days; } \\
\text { SC: } 25-65 \text { days) }\end{array}$} & \multirow[t]{3}{*}{$\begin{array}{l}\text { All surgeries } 3,5,14 \\
\text { Restart when there is no evidence } \\
\text { of infection, and wound healing is } \\
\text { satisfactory }\end{array}$} \\
\hline & $\begin{array}{l}162 \mathrm{mg} \mathrm{SC} \\
\text { q1-2weeks }\end{array}$ & $\begin{array}{l}\text { SC: } \\
5-13 \text { days }\end{array}$ & & \\
\hline & & & $\begin{array}{l}\text { All surgeries, option } 2^{10} \\
\text { Hold for } 26 \text { days }\end{array}$ & \\
\hline & & & $\begin{array}{l}\text { Total hip and total knee arthroplasty } \\
\text { Schedule surgery at the end of the } \\
\text { dosing interval (during week } 2 \text { or } 5 \text { ) }\end{array}$ & $\begin{array}{l}\text { Total hip and total knee arthroplasty } \\
\text { Restart at least } 14 \text { days after surgery, } \\
\text { when there is no evidence of infection, } \\
\text { and wound healing is satisfactory }\end{array}$ \\
\hline \multirow{3}{*}{$\begin{array}{l}\text { Tofacitinib } \\
\text { Psoriatic arthritis, } \\
\text { rheumatoid arthritis }\end{array}$} & IR: 5 mg twice daily & \multirow{3}{*}{$\begin{array}{l}\text { IR: } 3 \mathrm{~h} \\
\text { ER: } 6 \mathrm{~h}\end{array}$} & \multirow{2}{*}{$\begin{array}{l}\text { All surgeries }^{14} \\
\text { Hold for } 5 \times t_{1 / 2}(\text { IR: } 15 \text { h; ER: } 30 \mathrm{~h})\end{array}$} & \multirow{2}{*}{$\begin{array}{l}\text { All surgeries }{ }^{14} \\
\text { Restart when there is no evidence of } \\
\text { infection, and wound healing is } \\
\text { satisfactory }\end{array}$} \\
\hline & \multirow[t]{2}{*}{ ER: $11 \mathrm{mg}$ once daily } & & & \\
\hline & & & $\begin{array}{l}\text { Total hip and total knee arthroplasty } \\
\text { Schedule surgery } 7 \text { days after last dose }\end{array}$ & $\begin{array}{l}\text { Total hip and total knee arthroplasty } \\
\text { Restart at least } 14 \text { days after surgery, } \\
\text { when there is no evidence of infection, } \\
\text { and wound healing is satisfactory }\end{array}$ \\
\hline \multirow{4}{*}{$\begin{array}{l}\text { Ustekinumab } \\
\text { Psoriatic arthritis (SC) }\end{array}$} & \multirow{4}{*}{$\begin{array}{l}45-90 \mathrm{mg} \\
\text { SC q12weeks }\end{array}$} & \multirow[t]{4}{*}{$15-46$ days } & All surgeries & \multirow{3}{*}{$\begin{array}{l}\text { All surgeries } \\
\text { Restart when there is no evidence } \\
\text { of infection, and wound healing is } \\
\text { satisfactory }\end{array}$} \\
\hline & & & $\begin{array}{l}\text { Clean surgery } \neq \text { : } \\
\text { Hold for } 3 \times t_{1 / 2} \text { (45-138 days) }\end{array}$ & \\
\hline & & & $\begin{array}{l}\text { Contaminated/dirty surgery } 5 \\
\text { Hold for } 5 \times t_{1 / 2}(75-230 \text { days })\end{array}$ & \\
\hline & & & $\begin{array}{l}\text { Total hip and total knee arthroplasty } \\
\text { Schedule surgery at the end of the } \\
\text { dosing interval (during week 13) }\end{array}$ & $\begin{array}{l}\text { Total hip and total knee arthroplasty } \\
\text { Restart at least } 14 \text { days after surgery, } \\
\text { when there is no evidence of infection, } \\
\text { and wound healing is satisfactory }\end{array}$ \\
\hline
\end{tabular}

ER = extended release, IM = intramuscular, IR = immediate release, IV = intravenous, nr-Ax SpA = nonradiographic axial spondyloarthritis,

$\mathrm{PO}=$ by mouth (oral), SC = subcutaneous, SLE = systemic lupus erythematosus.

*Decision should always be individualized on the basis of clinical judgment and assessment of clinical factors.

†Approval by Health Canada, for adult patients with rheumatology conditions.

fIf bloodless surgery such as cataract, the UK National Health Service suggests to continue drug. ${ }^{5}$

$\S A d m i n i s t e r ~ 8 \mathrm{~g}$ of cholestyramine 3 times daily for 11 days to rapidly reduce leflunomide plasma levels. ${ }^{8}$

patient's risk of infection. ${ }^{3}$ If it is decided to hold the drug before surgery, a general guide of holding the drug for 2 to 5 half-lives may be used, unless the planned surgery is an elective total hip or total knee arthroplasty, for which use of the dosing-interval method is suggested. There is a general consensus that immunosuppressive therapy should be resumed when there is no evidence of infection and wound healing is satisfactory. Because clinical data and guidelines are few, there is a need for further research to develop a standardized approach for optimizing perioperative care of these patients. ${ }^{6,7}$

\section{References}

1. Module 9: Surgical site infection (SSI) event [procedure-associated module]. Centers for Disease Control and Prevention; 2020 [cited 2020 May 26]. Available from: https://www.cdc.gov/nhsn/pdfs/pscmanual/9pscssicurrent.pdf

2. Canadian surgical site infection prevention audit month February 2016: recap report. Canadian Patient Safety Institute; 2016 [cited 2019 May 5]. Available from: www.patientsafetyinstitute.ca/en/toolsResources/Documents/SSI Audit 2016_Recap Report EN.pdf

3. Bombardier C, Hazelwood GS, Akhavan P, Schieir O, Dooley A, Haraoui $\mathrm{B}$, et al. Canadian Rheumatology Association recommendations for the pharmacological management of rheumatoid arthritis with traditional and biologic disease-modifying antirheumatic drugs: part II safety. J Rheumatol. 2012;39(8):1583-602. 
This single copy is for your personal, non-commercial use only.

For permission to reprint multiple copies or to order presentation-ready copies for distribution, contact CHHP at publications@cshp.ca

4. Causes and risk factors of surgical site infections. In: Surgical site infections. Johns Hopkins University; [cited 2019 May 5]. Available from: https:// www.hopkinsmedicine.org/healthlibrary/conditions/adult/dermatology/ surgical_site_infections_134,144

5. Kerrigan N. Guidelines for the management of interruption of biologic therapies for elective surgery in adults and children with rheumatoid arthritis, JIA and ankylosing spondylitis. NHS Foundation Trust (UK): 2017.

6. Härle P, Straub RH, Fleck M. Perioperative management of immunosuppression in rheumatic diseases—what to do? Rheumatol Int. 2010; 30(8):999-1004.

7. Koons K, Plotas V, Tichansky DS, Kammerer MR. The safety of elective surgery with concurrent use of immunosuppressants. Glob Surg. 2017;3(2): $1-4$.

8. Heath Canada drug product database [database on internet]. Health Canada; [cited 2019 May 5]. Available from: https://health-products.canada.ca/ dpd-bdpp/index-eng.jsp

9. Goodman SM, Springer B, Guyatt G, Abdel MP, Dasa V, George M, et al. 2017 American College of Rheumatology/American Association of Hip and Knee Surgeons guideline for the perioperative management of antirheumatic medication in patients with rheumatic diseases undergoing elective total hip or total knee arthroplasty. Arthritis Care Res. 2017;69(8):1111-24.

10. Franco AS, Iuamoto LR, Pereira RM. Perioperative management of drugs commonly used in patients with rheumatic diseases: a review. Clinics. 2017;72(6):386-90.

11. Rosandich PA, Kelley JT, Conn DL. Perioperative management of patients with rheumatoid arthritis in the era of biologic response modifiers. Curr Opin Rheumatol. 2004;16(3):192-8.

12. Lexi-Drugs online [clinical database]. In: Lexicomp online. Wolters Kluwer; [cited 2019 May 5]. Accessed through institutional portal; subscription required to access content.

13. IBM Micromedex [database on internet]. IBM; [cited 2019 May 5]. Accessed through institutional portal; subscription required to access content.
14. Louthrenoo W, Kasitanon N, Katchamart W, Aiewruengsurat D, Chevaisrakul P, Chiowchanwisawakit P, et al. 2016 updated Thai Rheumatism Association recommendations for the use of biologic and targeted synthetic disease-modifying anti-rheumatic drugs in patients with rheumatoid arthritis. Int J Rheum Dis. 2017;20(9):1166-84.

Michelle Boyce, BSC, BScPharm, RPh, is with The Ottawa Hospital, Ottawa, Ontario. She is also a candidate for the ACPR (Accredited Canadian Pharmacy Residency) designation.

Anne Massicotte, BPharm, MSc, RPh, is with The Ottawa Hospital, Ottawa, Ontario.

Competing interests: None declared.

\section{Address correspondence to:}

Michelle Boyce

The Ottawa Hospital, General Campus

501 Smyth Road

Ottawa ON K1H 8L6

e-mail: mboyce@toh.ca

Funding: None received.

Acknowledgements: The authors would like to acknowledge Alexandra (Sascha) Davis, Librarian with The Ottawa Hospital, for her guidance with the literature search; and Yasmin Khaliq, who was at the time of the original submission a Pharmacist with the Ottawa Valley Regional Drug Information Centre and The Ottawa Hospital, for her presubmission editing assistance. 